\title{
Antiseptic Skin Preparation for Preventing Surgical Site Infection at Caesarean Section
}

\author{
Olufemi Aworinde1, Kehinde Olufemi-Aworinde², Akintunde Fehintola ${ }^{3}$, \\ Babalola Adeyemi ${ }^{4}$, Musliudin Owonikoko ${ }^{1}$, Adewale Samson Adeyemi ${ }^{*}$ \\ ${ }^{1}$ Department of Obstetrics and Gynaecology, LAUTECH Teaching Hospital, Ogbomoso, Nigeria \\ ${ }^{2}$ Department of Haematology and Blood Transfusion, Bowen University Teaching Hospital, Ogbomoso, Nigeria \\ ${ }^{3}$ Department of Obstetrics and Gynaecology, Bowen University Teaching Hospital, Ogbomoso, Nigeria \\ ${ }^{4}$ Department of Obstetrics and Gynaecology, Obafemi Awolowo University Teaching Hospital, Ile-Ife, Nigeria \\ Email: *waleadeyemi2004@gmail.com
}

Received 15 February 2016; accepted 18 March 2016; published 23 March 2016

Copyright (C) 2016 by authors and Scientific Research Publishing Inc.

This work is licensed under the Creative Commons Attribution International License (CC BY).

http://creativecommons.org/licenses/by/4.0/

(c) (i) Open Access

\section{Abstract}

Purpose: To compare the effect of chlorhexidine-alcohol and povidone iodine on surgical site infection (SSI) after caesarean section. Methodology: A randomized control trial of 374 patients (188 in the chlorhexidine-alcohol group and 186 in the povidone iodine group) who had elective caesarean section with no overt risk for SSI was done. Patients were followed up until thirty days after delivery to assess for symptoms and signs of SSI. Results: Fifty-one (13.6\%) of the study population developed SSI. Although the incidence of SSI was lower in the chlorhexidine-alcohol group than the povidone iodine group $(12.2 \%$ vs. $15.1 \% ; p=0.26)$; the difference was not statistically significant. The incidence of adverse skin reaction in Chlorhexidine-alcohol vs. povidone iodine was also not statistically significant $(4.0 \%$ vs. $5.4 \% ; p=0.40)$. Conclusion: The study demonstrates that there was no statistically significant difference in antiseptic property and side effect profile of chlorhexidine-alcohol and povidone-iodine when used as skin antisepsis in caesarean section.

\section{Keywords}

Antisepsis, Infection, Chlorhexidine, Povidone Iodine, Caesarean Section

\section{Introduction}

Surgical site infection (SSI) occurs in 5\% - 10\% of caesarean deliveries [1]. It causes significant morbidity and

"Corresponding author.

How to cite this paper: Aworinde, O., Olufemi-Aworinde, K., Fehintola, A., Adeyemi, B., Owonikoko, M. and Adeyemi, A.S. (2016) Antiseptic Skin Preparation for Preventing Surgical Site Infection at Caesarean Section. Open Journal of Obstetrics and Gynecology, 6, 246-251. http://dx.doi.org/10.4236/ojog.2016.64031 
mortality in these patients resulting in increased duration of hospitalization and cost of healthcare [2]. Considering the fact that caesarean section is the most common major obstetric surgery carried out on women worldwide, everything should be done to reduce the attendant morbidity and mortality [3].

The skin being a major source of pathogens that cause SSI, thus requires, proper preoperative skin preparation in order to decrease the likelihood of SSI [4]. Unfortunately, there is little evidence to guide the choice of antiseptic for skin preparation at surgery [5]. A Cochrane review on preoperative skin antiseptics for preventing surgical wound infections after clean surgery concludes that there is uncertainty about which antiseptic skin preparation is the most effective for preventing postoperative SSI [6]. A Cochrane review on skin preparation for preventing infection following caesarean section further suggests that there is a need for high-quality, properly designed randomized controlled trials with larger sample sizes especially comparing chlorhexidine-alcohol and povidone iodine [3]. The present study therefore aimed at comparing the effect of two different antiseptic skin preparations: chlorhexidine-alcohol and povidone iodine on surgical site infection rates post caesarean section in a Nigerian teaching hospital.

\section{Methods}

This randomized control trial was carried out in the Department of Obstetrics and Gynaecology of the Obafemi Awolowo University Teaching Hospitals Complex (OAUTHC), Ile-Ife, Osun State, Nigeria between August 2012 and July 2013. The study was approved by the Ethics committee of the hospital and all participants provided informed consent. Sample size was determined based on the formula for estimating sample size for the comparison of two independent population as described by Armitage et al. [7]. 15\% prevalence rate of SSI in povidone iodine group and a 70\% reduction (5\% prevalence) in chlorhexidine-alcohol group was used [1]. In order to make allowance for attrition, 35\% of the estimated sample size was added making 384 patients.

A total of 384 patients (192 in each of chlorhexidine-alcohol and povidone iodine group) who had elective caesarean section at OAUTHC, Ile-Ife were randomized into either group after informed consent was obtained. Patients with known allergy to chlorhexidine or povidone-iodine; immunocompromised patients and those with previous midline scar were excluded from the study. Patients with overt risk for infection like obstructed labour, prolong prelabour rupture of membranes, maternal febrile conditions were excluded.

Randomization was achieved using sequentially numbered sealed packets from a computer generated random sequence. The sealed envelopes were placed in the labour ward theatre and were drawn from serially by the surgeons just before the procedure. Blinding both patients and physicians to the antiseptic used for skin preparation (double-blinding) would have been ideal, however, it was not feasible in this trial. Systematic bias was minimised by using the same standard procedures of skin preparation, skin culture and assessment of outcomes.

Prior to surgery, all patients had a bath with a non-antiseptic soap to include the area of surgery. Shaving of the lower abdomen was done on the surgical table just before commencing antiseptic skin preparation. Subjects had pfannenstiel incision, which was closed with vicryl 2/0 subcuticular sutures. The subcutaneous layer was closed with vicryl 2/0. The surgery was done under spinal anaesthesia unless otherwise indicated. Demographic, obstetric, neonatal data and variables known to be related to SSI were recorded.

For patients who fell into the chlorhexidine-alcohol group, skin preparation with gauze soaked in Valon ${ }^{\circledR}$ (containing Chlorhexidine gluconate $0.3 \% \mathrm{w} / \mathrm{v}$ and Cetrimide 3.0\% w/v manufactured by Royal priesthood laboratory ltd) which was diluted with distilled water in a 1:1 ratio was done. A centrifugal scrubbing motion was used starting from the area of the intended incision and covered the abdomen from the subcoastal margin to the midaxillary line down to the middle of the thigh. This was repeated twice. The area was then dried with a piece of dry gauze in the same centrifugal manner. Moko ${ }^{\circledR}$ (containing Isopropyl alcohol 95\% v/v manufactured by New-Health way Co. Limited) was then applied on the area in the same centrifugal manner and allowed to dry before draping off the area.

For patients who fell into the povidone iodine group, Wosan ${ }^{\circledR}$ (containing $10 \%$ povidone iodine manufactured by Jawa international limited) was used. The povidone iodine was painted on the aforementioned area and then left to dry completely before draping the area and commencing the surgery.

The same prophylactic antibiotic-intravenous cefuroxime $750 \mathrm{mg}$ stat was administered after clamping of the cord. The placenta was removed with gentle traction and exterior massage of the uterus, and removed manually only if it was retained for more than 5 minutes. The uterus was then exteriorized before repair. On completion of the surgery, a standard sterile gauze dressing kept in place with plaster to ensure non-exposure of the gauze and 
underlying wound was applied. The patients were then counseled to keep the wound dressings dry.

Postoperatively, the patients' wound and area of the skin on which the antiseptics was applied were inspected on the third and seventh day. The dressing was changed on the third post operative day or earlier if soaked. Wounds that were determined to be infected had wound swabs taken for microscopy, culture and sensitivity and daily dressings instituted as appropriate. A modification of the Southampton's wound infection scoring system [8] was employed for grading infections when present.

After discharge, the women were instructed about the signs and symptoms of wound infection and they were given written information leaflets about SSI. Subjects were contacted weekly up to 30 days from delivery, to assess symptoms of surgical site infections. Patients who reported symptoms were evaluated at the obstetric emergency unit for surgical site infection.

Study data was processed using SPSS version 17 (IBM, Armonk, NY, USA). Frequency tables were made and results were tested for significance using the student t-test for continuous variables and chi square or Fisher exact test for categorical variables with level of significance $(x)$ set at 0.05 .

\section{Results}

Three hundred and eighty-four patients who had elective caesarean section were recruited into the study. Ten were excluded from the analysis due to the fact that they were lost to follow up or ended up having a midline scar. One hundred and eighty-eight were in the chlorhexidine-alcohol group and one hundred and eighty-six in the povidone iodine group.

Table 1 shows the sociodemographic characteristics and perioperative characteristics of patients in both groups. There was no statistically significant difference between both groups in terms of their characteristics.

Table 2 shows development of skin reaction by type of antiseptic used. Eighteen (4.8\%) of the patients recruited developed skin reactions following administration of the skin antiseptic.

Table 3 shows that fifty-one (13.6\%) of the total study population developed surgical site infection. There was however no statistically significant difference between the chlorhexidine-alcohol group and the povidone iodine group (23, $12.2 \%$ ) vs. $28,15.1 \%) ; p=0.26$.

\section{Discussion}

The incidence of $13.6 \%$ for SSI in this study was comparable to the incidence of $10 \%$ finding by Fasubaa et al. [9], but lower than the $23.4 \%$ got by Makinde [10] from the same centre. The SSI rate of $13.6 \%$ in this study is similar to the findings of other workers in Nigeria [11] [12]. It should be noted that although the rate of $13.6 \%$ is within $0 \%$ to $20.5 \%$ reported by Moir-Bussy and colleagues in a hospital survey in London, it is much higher than figures reported from most developed countries [13].

The findings from this study show that there is no statistically significant difference in the incidence of SSI $(12.2 \%$ vs. $15.1 \%$; $p=0.26)$ in both groups. Although there was a $19 \%$ reduction in incidence of SSI in the chlorhexidine-alcohol group, this was lower than the findings of Darouchie et al. [4] where a $41 \%$ reduction (9.5\% vs. $16.1 \%, \mathrm{p}=0.004)$ was found in the chlorhexidine-alcohol group and with the work of Levin et al. [1] where a $69 \%$ reduction in SSI $(14.6 \%$ vs. $4.5 \%, \mathrm{p}=0.011)$ was found in the chlorhexidine-alcohol group. In the two cited studies the difference was statistically significant. The lower benefit gotten in the present study compared to the two cited studies might be due to the fact that the studies were done in general surgical and gynaecological patients respectively. Berry et al. also compared povidone iodine with chlorhexidine-alcohol in 371 patients undergoing clean surgery. Significantly more patients $(28 / 176 ; 15.9 \%)$ in the povidone iodine group developed an infection compared with the patients cleansed with chlorhexidine (8/195; 4.1\%) [14]. Unfortunately, there is no known literature regarding surgical site infection rates using chlorhexidine-alcohol and povidone iodine in elective caesarean section with which the findings of this study could be compared.

The finding of beneficial effect of chlorhexidine-alcohol over povidone iodine, however, contrasts with the findings of Swenson et al. [15] in general surgical patients, where they found that iodine containing antiseptics were more protective against the development of SSI than chlorhexidine-alcohol containing antiseptics.

A Cochrane review of skin preparation for preventing infection following caesarean section [3] found no significant difference in the incidence of SSI between skin antiseptics used in the six trials included in the review. Of the five trials included none compared chlorhexidine alcohol with povidone iodine. The reviewers concluded that "little evidence was available from the included randomised controlled trials to evaluate different agent 
Table 1. Characteristics of patients.

\begin{tabular}{|c|c|c|c|c|}
\hline Characteristic & $\begin{array}{c}\text { Total patient } \\
\text { population } \\
\mathrm{N}=374\end{array}$ & $\begin{array}{c}\text { Chlorhexidine-alcohol group } \\
\qquad \mathbf{N}=\mathbf{1 8 8}\end{array}$ & $\begin{array}{l}\text { Povidone iodine } \\
\text { group } N=186\end{array}$ & $P$ value \\
\hline Mean age (years) & $32.01 \pm 6.13$ & $32.13 \pm 6.03$ & $31.89 \pm 6.25$ & 1.00 \\
\hline Parity & $1.61 \pm 0.42$ & $1.60 \pm 0.59$ & $1.70 \pm 0.64$ & 0.84 \\
\hline \multicolumn{5}{|l|}{ Social class } \\
\hline I & $156(41.7 \%)$ & 75 (39.9\%) & $81(43.5 \%)$ & \multirow{5}{*}{0.25} \\
\hline II & $133(35.6 \%)$ & $66(35.1 \%)$ & $67(36.0 \%)$ & \\
\hline III & $69(18.4 \%)$ & $41(21.8 \%)$ & $28(15.1 \%)$ & \\
\hline IV & $15(4.0 \%)$ & $5(2.7 \%)$ & $10(5.4 \%)$ & \\
\hline $\mathrm{V}$ & $1(0.3 \%)$ & $1(0.5 \%)$ & 0 & \\
\hline \multicolumn{5}{|l|}{ Tribe } \\
\hline Yoruba & 277 (74.1\%) & 139 (73.9\%) & 138 (74.2\%) & \multirow{4}{*}{1.00} \\
\hline Ibo & $59(15.8 \%)$ & $30(16.0 \%)$ & $29(15.6 \%)$ & \\
\hline Hausa & $20(5.3 \%)$ & $10(5.3 \%)$ & $10(5.4 \%)$ & \\
\hline Others & $18(4.8 \%)$ & $9(4.8 \%)$ & $9(4.8 \%)$ & \\
\hline \multicolumn{5}{|l|}{ Occupation } \\
\hline Professional & $140(37.4 \%)$ & 70 (37.2\%) & 70 (37.6\%) & \multirow{4}{*}{0.93} \\
\hline Artisan & $60(16.0 \%)$ & 28 (14.9\%) & $32(17.3 \%)$ & \\
\hline Housewife & $96(25.7 \%)$ & $50(26.6 \%)$ & $46(24.7 \%)$ & \\
\hline Student & $78(20.9 \%)$ & $40(21.3 \%)$ & $38(20.4 \%)$ & \\
\hline \multicolumn{5}{|l|}{ Educational status } \\
\hline Tertiary & 204 (54.5\%) & 104 (55.3\%) & 100 (53.8\%) & \multirow{4}{*}{0.98} \\
\hline Secondary & $112(29.9 \%)$ & $55(29.3 \%)$ & $57(30.6 \%)$ & \\
\hline Primary & 35 (9.4\%) & $18(9.6 \%)$ & $17(9.1 \%)$ & \\
\hline No formal education & $23(6.1 \%)$ & $11(5.8 \%)$ & $12(6.5 \%)$ & \\
\hline Body mass index & $23.75 \pm 3.33$ & $23.70 \pm 3.26$ & $23.81 \pm 3.43$ & \multirow{4}{*}{0.98} \\
\hline Normal & $280(74.9 \%)$ & $141(75.0 \%)$ & $139(74.7 \%)$ & \\
\hline Over weight & $61(16.3 \%)$ & $31(16.5 \%)$ & $30(16.1 \%)$ & \\
\hline Obese & $33(8.8 \%)$ & $16(8.5 \%)$ & $17(9.2 \%)$ & \\
\hline \multicolumn{5}{|l|}{ Indications for surgery } \\
\hline $\begin{array}{l}1 \text { caesarean section + } \\
\text { another complication }\end{array}$ & $115(30.7 \%)$ & $61(32.4 \%)$ & $54(29.0 \%)$ & \multirow{7}{*}{0.13} \\
\hline Major placenta praevia & 54 (14.4\%) & $32(17.0 \%)$ & $22(11.8 \%)$ & \\
\hline 2 previous $\mathrm{C} / \mathrm{S}$ or more & $53(14.3 \%)$ & $27(14.4 \%)$ & $26(14.0 \%)$ & \\
\hline Abnormal lie at term & $43(11.5 \%)$ & $24(12.8 \%)$ & $19(10.2 \%)$ & \\
\hline Previous uterine surgery & $24(6.4 \%)$ & $12(6.4 \%)$ & $12(6.5 \%)$ & \\
\hline Breech presentation & $45(12.0 \%)$ & $20(10.6 \%)$ & $25(13.4 \%)$ & \\
\hline Others & $40(10.7 \%)$ & $12(6.4 \%)$ & $28(15.1 \%)$ & \\
\hline \multicolumn{5}{|l|}{ Duration of surgery } \\
\hline Less than 1 hour & 371 (99.2\%) & 187 (99.5\%) & 184 (98.9\%) & \multirow[t]{2}{*}{0.56} \\
\hline More than 1 hour & $3(0.8 \%)$ & $1(0.5 \%)$ & $2(1.1 \%)$ & \\
\hline \multicolumn{5}{|l|}{ Anaesthesia used } \\
\hline Spinal & 371 (99.2\%) & 186 (98.9\%) & 185 (99.5\%) & \multirow[t]{2}{*}{0.57} \\
\hline General & $3(0.8 \%)$ & $2(1.1 \%)$ & $1(0.5 \%)$ & \\
\hline
\end{tabular}

Table 2. Development of skin reaction by type.

\begin{tabular}{cccc}
\hline Type of skin reaction & $\begin{array}{c}\text { Chlorhexidine-alcohol } \\
\text { group } \mathbf{N}=\mathbf{1 8 8}\end{array}$ & $\begin{array}{c}\text { Povidone iodine group } \\
\mathbf{N}=\mathbf{1 8 6}\end{array}$ & $\begin{array}{c}\text { Total } \\
\mathbf{N}=\mathbf{3 7 4}\end{array}$ \\
\hline Any skin reaction & $8(4.4 \%)$ & $10(5.4 \%)$ & $18(4.8 \%)$ \\
Pruritus & $4(2.2 \%)$ & $6(3.2 \%)$ & $10(2.7 \%)$ \\
Erythema & $4(2.2 \%)$ & $4(2.2 \%)$ & $8(2.1 \%)$ \\
\hline
\end{tabular}


Table 3. Development of surgical site infection by type and microorganism.

\begin{tabular}{ccccc}
\hline Type of surgical site infection & $\begin{array}{c}\text { Chlorhexidine-alcohol } \\
\text { group N = 188 }\end{array}$ & $\begin{array}{c}\text { Povidone iodine group } \\
\mathbf{N}=\mathbf{1 8 6}\end{array}$ & $\begin{array}{c}\text { Total } \\
\mathbf{N}=374\end{array}$ & P value \\
\hline $\begin{array}{c}\text { Any type of surgical site infection } \\
\text { I Normal healing with mild } \\
\text { bruising or erythema }\end{array}$ & $23(12.2 \%)$ & $28(15.1 \%)$ & $51(13.6 \%)$ & 0.26 \\
$\begin{array}{c}\text { II Erythema plus other } \\
\text { signs of inflammation }\end{array}$ & $3(1.6 \%)$ & $4(2.2 \%)$ & $7(1.9 \%)$ \\
III Clear or haemoserous discharge & $7(3.7 \%)$ & $10(5.3 \%)$ & $17(4.5 \%)$ \\
$\quad 7(3.7 \%)$ & $6(3.2 \%)$ & $13(3.5 \%)$ \\
IV Pus & $5(2.7 \%)$ & $7(3.8 \%)$ & $2(0.5 \%)$ \\
with/without tissue breakdown & $1(0.5 \%)$ & $1(0.5 \%)$ & \\
Microorganism cultured & & & $21(5.6 \%)$ \\
$\quad$ Staphylococcus aureus & $10(5.3 \%)$ & $11(5.9 \%)$ & $14(24.1 \%)$ \\
$\quad$ Escherichia coli & $6(3.2 \%)$ & $8(4.3 \%)$ & $6(3.7 \%)$ \\
Pseudomonas aeruginosa & $3(1.6 \%)$ & $3(1.6 \%)$ & $10(2.7 \%)$ \\
$\quad$ Proteus mirabilis & $4(2.1 \%)$ & $6(3.2 \%)$ &
\end{tabular}

forms, concentrations and methods of skin preparation for preventing infection following caesarean section” [3].

Most of the cases of SSI were of the superficial type which was similar to findings of other investigators [13] [16]. In this study, the commonest causative organism isolated for SSI was Staphylococcus aureus followed by Escherichia coli. This is similar to the findings of other investigators in Ile-Ife [16] [17]. Shittu et al. [17] found that Staphylococcus species made up about $41 \%$ of the isolates from infected wounds while Adisa et al. [16] found that Staphylococcus aureus made up $62.5 \%$ of the isolates found in their study. This is in keeping with the fact that most SSI occurs from commensal organisms such as Staphylococci species which are consistently present on a patient's skin, compared with transient organisms that are more easily removed [18].

Incidence of skin reaction was found to be higher in the povidone iodine group than the chlorhexidine-alcohol group. The reaction consisted mainly of pruritus and erythema but none was life threatening. These reactions were attributed to the antiseptic because they involved the entire area the antiseptic was used on and not just the incision site.

The true incidence of chlorhexidine allergy is unknown [19]. However, it is believed that it is more prevalent than quoted and cases may have been overlooked due to the nature of the reaction and lack of suspicion of chlorhexidine as a culprit [20]. Incidence varies from $0.47 \%$ - 5\% [19] [20]. The incidence of 5\% gotten by Apisarnthanarak et al. [20] is similar to the findings of $4.4 \%$ in this study. Povidone iodine is also known to be associated with adverse reactions ranging from minor skin irritation to anaphylaxis [21], although like chlorhexidine, pruritus is the most commonly reported allergic reaction. Most reports of povidone iodine allergy in the literature are case reports making comparison of the incidence gotten in this study with previous works almost impossible.

The result of this study shows that although chlorhexidine-alcohol skin antiseptic has some benefit over povidone iodine in terms of lower incidence of SSI and skin reaction, the evidence is not sufficient enough to recommend it over povidone iodine. The study goes further to serve as a reference for future work involving skin antiseptics and caesarean section.

\section{Acknowledgements}

We thank Consultant staff and members of the Department of Obstetrics and Gynaecology Obafemi Awolowo University Teaching Hospital Complex, Ile-Ife, Osun state.

\section{References}

[1] Levin, I., Amer-Alshiek, J. and Avni, A. (2011) Chlorhexidine and Alcohol versus Povidone-Iodine for Antisepsis in Gynecological Surgery. Journal of Women's Health, 20, 321-324. http://dx.doi.org/10.1089/jwh.2010.2391 
[2] Center for Disease Control and Prevention (2011) Data and Statistics for Surgical Site Infections. http://www.cdc.gov/ncidod/dhqp/dpac_ssi_data.html

[3] Hadiati, D.R., Hakimi, M. and Nurdiati, D.S. (2012) Skin Preparation for Preventing Infection Following Caesarean Section. Cochrane Database of Systematic Reviews, 9, Article No: CD007462. http://dx.doi.org/10.1002/14651858.CD007462.pub2

[4] Darouiche, R.O., Wall, M.J., Itani, K.M., Otterson, M.F., Webb, A.L., Carrick, M.M., et al. (2010) Chlorhexidine-Alcohol versus Povidone-Iodine for Surgical Site Antisepsis. The New England Journal of Medicine, 362, 18-26. http://dx.doi.org/10.1056/NEJMoa0810988

[5] Napolitano, L.M. (2006) Decolonization of the Skin of the Patient and Surgeon. Surgical Infections, 7, S3-S15. http://dx.doi.org/10.1089/sur.2006.7.s3-3

[6] Edwards, P., Lipp, A. and Holmes, A. (2004) Preoperative Skin Antiseptics for Preventing Surgical Wound Infections after Clean Surgery. Cochrane Database of Systematic Reviews, 3, Article No: CD003949. http://dx.doi.org/10.1002/14651858.CD003949.pub2

[7] Armitage, P., Berry, G. and Matthews, J.N.S. (2002) Statistical Methods in Medical Research. 4th Edition, Blackwell Science, Oxford. http://dx.doi.org/10.1002/9780470773666

[8] Lorenz, R.P., Botti, J.J. and Appelbaum, P.C. and Bennett, N. (1988) Skin Preparation Methods before Cesarean Section: A Comparative Study. The Journal of Reproductive Medicine, 33, 202-204.

[9] Fasubaa, O.B., Ogunniyi, S.O., Dare, F.O., Isawumi, A.I. and Ezechi, O.C. (2000) Uncomplicated Caesarean Section: Is Prolonged Hospital Stay Necessary? East African Journal of Medicine, 77, 36-39.

[10] Makinde, O.O. (1987) A Review of Caesarean Section at the University of Ife Teaching Hospitals. Tropical Journal of Obstetrics and Gynaecology, 6, 26-30.

[11] Ezechi, O.C., Edet, A., Akinlade, H., Gab-Okafor, C.V. and Herbertson, E. (2009) Incidence and Risk Factors for Caesarean Wound Infection in Lagos Nigeria. BMC Research Notes, 2, 186. http://dx.doi.org/10.1186/1756-0500-2-186

[12] Ojiyi, E.C., Dike, E.I., Okeudo, C., Ejikem, E.C. and Nzewuihe, A.C.E. (2013) Wound Infection Following Caesarean Section in a University Teaching Hospital in South-East Nigeria. Orient Journal of Medicine, 25, 8-13.

[13] Moir-Bussy, B.R., Hutton, R.M. and Thompson, J.R. (1984) Wound Infection after Caesarean Section. Journal of Hospital Infection, 5, 359-370. http://dx.doi.org/10.1016/0195-6701(84)90003-3

[14] Berry, A., Watt, B., Goldacre, M., Thomson, J. and McNair, T.A. (1982) A Comparison of the Use of Povidone-Iodine and Chlorhexidine in the Prophylaxis of Postoperative Wound Infection. Journal of Hospital Infection, 3, 55-63. http://dx.doi.org/10.1016/0195-6701(82)90031-7

[15] Swenson, B.R., Hedrick, T.L., Metzger, R., Bonatti, H., Pruett, T.L. and Sawyer, R.G. (2009) Effects of Preoperative Skin Preparation on Postoperative Wound Infection Rates: A Prospective Study of 3 Skin Preparation Protocols. Infection Control and Hospital Epidemiology, 30, 964-971. http://dx.doi.org/10.1086/605926

[16] Adisa, A.O., Lawal, O.O. and Adejuyigbe, O. (2011) Evaluation of Two Methods of Preoperative Hair Removal and Their Relationship to Postoperative Wound Infection. The Journal of Infection in Developing Countries, 5, 717-722. http://dx.doi.org/10.3855/jidc.1527

[17] Shittu, A.O., Kolawole, D.O. and Oyedepo, E.A.R. (2002) A Study of Wound Infections in Two Health Institutions in Ile-Ife, Nigeria. African Journal of Biomedical Research, 5, 97-102.

[18] Reichman, D.E. and Greenberg, J.A. (2009) Reducing Surgical Site Infections: A Review. Reviews in Obstetrics and Gynecology, 2, 212-221.

[19] Nakonechnaa, A., Dorea, P., Dixonb, T., Khanc, S., Deacockc, S., Holdinga, S., et al. (2012) Immediate Hypersensitivity to Chlorhexidine Is Increasingly Recognised in the United Kingdom. Allergologia et Immunopathologia, 42, 44-49. http://dx.doi.org/10.1016/j.aller.2012.08.001

[20] Apisarnthanarak, A. and Mundy, L.M. (2011) High Incidence of Chlorhexidine-Induced Rash among Thai Health Care Workers. Clinical Infectious Diseases, 53, 848-849. http://dx.doi.org/10.1093/cid/cir518

[21] Rahimi, S. (2010) Late-Onset Allergic Reaction to Povidone Iodine Resulting in Vulvar Edema and Urinary Retention. Obstetrics \& Gynecology, 116, 562-564. http://dx.doi.org/10.1097/AOG.0b013e3181e91fa3 